\title{
A FUNCTIONAL-SYNTACTIC PERSPECTIVE ON GENDER STEREOTYPING IN POPULAR FICTION
}

\author{
E. Hilton Hubbard \\ Department of Linguistics \\ University of South Africa
}

In popular fiction - particularly in romances - males tend to be portrayed as active, dominant characters while the females are assigned much more passive roles. The main aim of this paper is to show how an understanding of syntax - more specifically of transitivity functions in systemic grammar - can promote keener awareness of how the writer's use of language gives effect to this form of gender stereotyping. The classroom relevance of the kind of stylistics applied here - and, for that matter, the classroom relevance of popular fiction - will also be briefly considered.

Athough the main focus of this study is popular romantic fiction, a sample of "art" fiction was also analysed. Given that on one level of interpretation, Jane Austen's Pride and Prejudice could be characterised as a romance, extracts from this work were compared to samples of popular romance writing in order to see to whint extent the syntax of the different authors "discriminates" between their male and female characters. This comparison of stylistic traits in art fiction and popular fiction texts is also appropriate in the context of the general pedagogical argument that will be put forward in more detail later, namely that popular and canonical "literature" should be juxtaposed and compared in the classroom.

In what ways does gender stereotyping manifest itself in the context of popular fiction? At one level -readership - it can be said of such fiction that it has "its base in conventional assumptions about maleness and femaleness, and [...] appeal[s] to these assumptions" and that there is "an implicit assumption that men like their stories to be 'action-packed', whereas women prefer a "heart-warming" tale" (Carter and Nash 1990:100). In popular fiction, then, there is a considerable amount of gender-based targeting of readership, and it might be argued that this is particularly true of the genre we are concerned with, namely the romance, which is aimed at women readers.

In keeping, then, with the conventional assumptions about preferences of women readers, writers of popular romances seem to indulge in gender stereotyping at a second level, namely that of character portrayal. Strongly emphasised are the female characters' states of feeling - they are 
the emotion-driven subjects to the men as active objects: they feel rather than do. Consequently, a pervasive feature of romance fiction is that "heroines do not act, but are acted upon" (Carter and Nash 1990:107). Indeed, they might often be seen as victims of uncontrollable forces (not least of which are their own emotions). The following extract from The Enerald Garden exemplifies these features of the genre rather well (Britt 1976:19-20).

Her voice was not as hard as she tried to make it and he looked at her curiously.

"So you have a conscience. Like to talk about it?"

Vinney shook her head. The softening of his deep voice beckoned the tears to her throat and she began to scarch in her handbag for her make-up. It would never do for her family to see she had been crying. As for the man beside her, Virney had to admit that his concern touched her very deeply. The dark eyes looked at her so intently, the rather thin-lipped mouth that charmed alarmingly and the decp brown voice so filled with concern - he was the most exciting man she had ever met. He had to be to trake her so conscious of his charms at a time when life held no meaning any more. [...]

Tactfully he had switched on the lights and started the car as she spread foundation and powder over her face, and with new make-up on her courage returned.

Extracts such as this were analysed in an attempt to answer the question: If the heroines of popular romance are perceived as more passive than their male counterparts, what role does the writer's syntax play in communicating this perception? Closely related to this is the issue of which aspects of syntax, within which linguistic models, are most likely to yield insightful answers to this question.

A functional model, here Hallidayan systemic-functional grammar, and specifically the system of transitivity within that model, seemed to offer good prospects for accounting at least partially for the reader perceptions at issue. The transitivity system in terms of which clauses can be described has been defined as follows:

It is concerned with a coding of the goings on: who docs what in relation to whom/what, where, when, how and why. Thus the analysis is in terms of some PROCESS, its PARTICIPANTS, and the CIRCUMSTANCES pertinent to the Process-Participant configuration (Hasan 1988:63). 
language in literary texts. What is by now the classic of its sort is Halliday's analysis of William Golding's The Inheritors (Halliday 1973). Halliday's aim was to show how an analysis based on transitivity could help to distinguish the world-view that characterised the more primitive "people ${ }^{n}$ of the novel on the one hand and the "inheritors", the members of the "tribe", on the other. He finds in his analysis of passages depicting the "people" that a picture emerges where "people act, but they do not act on things; they move, but they move only themselves, not other objects", and where "a high proportion (exactly half) of the subjects are not people; they are either parts of the body [...] or inanimate objects [...], and of the human subjects half again [...] are found in clauses which are not clauses of action" (Halliday 1973:123).

Clearly, this kind of analysis is relevant to the issue of the relative passivity of different fictional characters. Kies (1992) focuses specifically on this question of passivity in his discussion of Orwell's 1984 , adducing 14 different syntactic devices that he sees as undercutting the degree of "agency" that the central character of the novel is permitted. The approach here is loosely based on systemic grammar. A more specific focus on transitivity is found in Kennedy's (1982) discussion of the role it plays in the depiction of the main players in Conrad's The Secret Agent and Joyce's short story, Two Gallants.

What emerges from a closer scrutiny of the studies just mentioned is the prime relevance, within the system of transitivity, of participant roles to our response to fictional characters:

... part of the basis of our perecption of what a person is like derives from knowing what sort of Participant rolcs are ascribed to that person (Hasan 1988:65).

In terms of this functional-syntactic perspective, a nimate and inanimate objects (the participants) take up various possible roles (similar to the case roles of Filmorean case grammar (Fillmore 1977)) relative to the process depicted by the clause. These roles differ in the degree to which the relevant participant is active rather than passive, i.e. what Hasan calls their effectuality or dynamism:

If we define effectuality - or dynamism - as the quality of being able to affect the world around us, and of bringing change into the surrounding environment, the semantic value of the various [...] roles must be seen as distinct (Hasan 1989:45).

Hasan further refines and extends the linguistic stylistic potential of the transitivity system by positing a cline of dynamism along which the various participant roles can be ranged, from most 
active to most passive (Hasan 1989:46), and this construct informs her stylistic analysis of certain poems (Hasan 1988; 1989)

The participant roles and the clyne of dynamism are key features of my analysis of extracts from romance fiction, and in order to clarify both concepts, examples of each role, drawn from the extracts, will now be considered - in order of dynamism, from most to least dynamic (coded accordingly, from 1 to 12 ).

\section{Al Actor (t Animate Goal)}

The participant role of Actor has been defined as "the 'logical subject' of older terminology, and means the one that does the deed" (Halliday 1985:103). In terms of the transitivity system, the process in which some participant performs as an Actor is termed a material process (Halliday 1985:103). The most dynamic "deed" is seen as one that directly affects animate participants (as Goals), and the Actor can also be a body part, as in [3] below:

[1] he swung her up onlo his own saddle

[2] he drew her irresistably closer against his own tough body

[3] fingers as strong as steel were urging her inside the roomy car

\section{A2 Actor (+ Inanimate Goal)}

14] tactully he had switched on the car lights and started the car

15] she wiped her pale checks and wet eyes

[6] she spread foundation and powder over her face

\section{S3 Soyer (+ Recipient)}

Sayer is seen as a relatively dynamic role, involved in verbal process clauses (Halliday 1985:129), and defined as "anything that puts out a signal, like the notice or my watch" (Halliday 1985:129), and it does of course include human speakers, as in: 
(7) she was calling to her to hold on

[8] he assured her

[9] she addressed him

\section{\$4 Sayer}

This role is seen as less dynamic when there is no overt Recipient, as in:

$[10]$ she accused bitterly

[11] she asked miserably

[12] she said frigidly

\section{P5 Phenomenon (+ Senser)}

Phenomenon and Senser are the main participants in mental process clauses, where the Senser is "the conscious being that is feeling, thinking or seeing", while the Phenomenon is "that which is sensed - felt, thought or seen" (Halliday 1985:111). The role of Phenomenon is seen as the more dynamic one as it might be said to trigger the relevant mental process:

[13] she was really angered by the taunt

[14] he disliked her

[15] his sudden smile startled her

\section{S6 Senser}

In [13] - [15] above, the Senser role is present together with the Phenomenon role, but clauses may include Senser roles only, as in:

[16] she thought agitatedly 
A7 Actor

The role of Actor in intransitive clauses is not given nearly as high a rating in Hasan's cline of dynamism as it is in transitive cláuses (hence $A 7$ as opposed to $A 1$ and $A 2$ above):

[17] Vinney leant back in her seat

[18] she turned away from his mocking, knowing eyes

[19] her voice slid on ice

\section{B8 Behaver}

Behavioural processes are "processes of physiological and psychological behaviour, like breathing, dreaming, smiling, coughing" (Halliday 1985:128). Halliday admits to a certain fuzziness between this category of process and material processes, and hence between the roles of Actor and Behaver (a fuzziness which of course affects all grammars with a strong semantic orientation, but space prevents this issue from being considered further here). Behavioural processes could be seen as less under voluntary control than material processes, and some fairly clear examples include:

[20] Sabrina shivered

[21] she swallowed on a dry throat

\section{C9 Camier}

This is "the entity to which some attribute is ascribed" - a participant in a relational process (Halliday 1985:113):

[23] he was the most exciting man she'd ever met

[24] her voice was low, sweet and husky 


\section{B10 Beneficiary}

The Beneficiary is "the one to whom or for whom the process is said to take place" (Halliday 1985:132): he opened the door for her

\section{GII Goal}

As seen in [1] - [6] above, the Goal is the role of "the one to which the process is extended" (Halliday 1985:103), exemplified also in:

$[26]$ sleep was slowly claiming her

\section{C12 Circumstance} the tears forcing their way between her lashes there was authority in that mouth, yet in the full lower lip lurked a hint of volcanic passion

The examples provided above help to illustrate the transitivity roles and the cline of dynamism while at the same time conveying something of the flavour of the language used to describe the main male and female characters in the novels selected. Let us now return to the central question of this study: If the heroines of popular romance are perceived as more passive than their male counterparts, what role does the writer's syntax play in communicating this perception?

In an attempt to develop an at least preliminary answer to this question, a transitivity analysis of certain clauses in two popular romances (Britt 1976 and Ker 1985) and in Pride and Prejudice (Austen 1963 [1813]) was undertaken. The first passages in each novel in which the main male and the main female character are in one another's presence were identified and then within those passages the first 50 instances in which each character featured in a participant role were analysed. Body parts and other physical aspects of the characters were included in the analysis (see, for example, [3], [15], [19], [24], [27] and [28]).

The results of the analysis are presented in Table 1 . The participant roles are listed from most 
dynamic to least dynamic and the number of occurrences for each amongst the male and the female characters in the popular romances (Nick and Vinney from Britt (1976) and Leo and Sabrina from Ker (1985)) are indicated and then totalled, followed by the total for the main "romantic" pairing of characters in Pride and Prejudice (Darcy and Elizabeth).

Table 1

Popular romances

MEN

$\begin{array}{lccc}\text { Role } & \text { Nick } & \text { Lco } & \text { Tot } \\ \text { Actor1 } & 4 & 8 & 12 \\ \text { Actor2 } & 11 & 2 & \mathbf{1 3} \\ \text { Sayer3 } & - & - & - \\ \text { Sayer4 } & 10 & 11 & 21 \\ \text { Phenom5 } & 3 & 1 & 4 \\ \text { Senser6 } & 1 & 1 & \mathbf{2} \\ \text { Actor7 } & 3 & 4 & 7 \\ \text { Behaver8 } & 11 & 7 & \mathbf{1 8} \\ \text { Carrier9 } & 3 & 6 & 9 \\ \text { Recip10 } & 1 & 1 & \mathbf{2} \\ \text { Goal11 } & 2 & 2 & 4 \\ \text { Circum 12 } & - & 3 & \mathbf{3} \\ \text { Total } & 50 & 50 & 100\end{array}$

\section{$P$ and $P$}

\section{WOMEN}

$\begin{array}{ccccc}\text { Vin } & \text { Sab } & \text { Tot } & \text { Dar } & \text { Ell } \\ - & 2 & 2 & 2 & 2 \\ 4 & 1 & 5 & 4 & 1 \\ 1 & - & 1 & 2 & 3 \\ 4 & 11 & 15 & 12 & 11 \\ - & - & - & 1 & 3 \\ 3 & 3 & 6 & 10 & 3 \\ 7 & 7 & 14 & 1 & 3 \\ 12 & 10 & 22 & 5 & 3 \\ 1 & 2 & 3 & 1 & 4 \\ 1 & - & 1 & 1 & 1 \\ 7 & 6 & 13 & 6 & 5 \\ 5 & 7 & 12 & 4 & 8 \\ 50 & 50 & 100 & 50 & 50\end{array}$

Although quantities in this preliminary study are small, certain tendencies do emerge from the comparative statistics which support the hypothesis that the females of popular romances are indeed more passive than the males. In terms of $\mathrm{Ch}^{2}$ calculations, the most striking difference is at the highest level of dynamism, Actor 1 , with 12 occurrences for the men and only 2 for the women in the popular romances. Clearly, it is the men who act on others, and the women are often cast syntactically as their Goals. There are 13 instances of women in Goal roles and only 4 of men, this being the third greatest statistical difference. The second greatest difference in the sample affects the role even lower on the scale of dynamism than Goal, namely Circumstance. This reveals a female versus male count of 12 against 3 . At the other end of the scale, we see a considerable difference with respect to Actor 2, with males in this role outnumbering females by 13 to 5 . 
There is then a fairly marked gender-based distinction as revealed by the data, with men featuring much more substantially in the two most dynamic roles and women in the two least dynamic roles. Interestingly, women are also strongly in the majority in the role of Actor 7 . Thus when they do act, their actions are not presented as having an effect on people or things. The women also tend to be Sensers, with the men in Phenomenon roles, and what we have here of course is a reflection of the point of view adopted in the popular romance, where the men are seen through the eyes of the central female character.

In Pride and Prejudice, by comparison, Darcy appears more often in the Senser role, and Elizabeth in that of Phenomenon, though the statistical quantities are very limited. In other respects, the two characters do not appear to differ much in terms of the dynamism of the roles they participate in.

We find, therefore, that impressions of gender stereotyping in popular romance fiction - as opposed to "serious" fiction - do indeed appear to be at least partially explicable in terms of the transitivity analysis undertaken here. The corpus in this study was small, but the indications are that a larger-scale analysis would corroborate this finding.

A case has now been made for the relevance of a certain kind of syntactic analysis to a linguistic stylistic problem. The question that remains is the applied one, i.e. What insights does this sort of linguistic stylistics offer the teaching profession? I would like in conclusion to attempt a brief answer in terms of two subsidiary questions:

(a) Why do (linguistic) stylistics in the classroom, making use also of popular fiction?; and

(b) Why do (linguistic) stylistics in the chassroom at all?

These two questions are of course closely related, but we can first consider the advantages of using popular literature in the classroom:

For the weaker reader and the second-language student in particular, there is an abundance of suitably short texts, written in relatively accessible language.

It is "popular" also in the sense that many students prefer it to serious literature and thus it is not stigmatised as "academic" reading, imposed from above. 
There can be little dowbt that bringing popular literature into the classroom will lead easily to novel, learner-centred activities. Similarities and differences between popular and serious literature can be explored in such a way that students will be able to appreciate much more directly why some literature is more highly regarded. The symbolism, allusion, intertextuality and aesthetically motivated language patterning typical of such literature can be contrasted with the stock or ad hoc patterning of more popular work.

- Popular fiction also reflects the tastes of the society that spawns it and is therefore a sociocultural phenomenon worthy of study in its own right. We have seen how one topical sociopolitical issue - gender (and gender stereotyping) - can be approached through analysis of the language of the popular romance.

There are, then, a number of reasons why a systematic exploration of popular fiction should be included in school and university literature curricula, as indeed is happening increasingly in Britain today (Carter 1988:63). It is probably true to say that this is in large measure thanks to burgeoning interest amongst literature scholars and teachers in linguistic approaches to texts, be these popular or part of the literary canon.

This leads us to the broader question: Why do (linguistic) stylistics in the classroom at all?

There is a fast growing body of literature on the role of stylistics in the classroom and space constraints prevent a thorough account of the issue here. Widdowson (1975) is now a classic exponent of the genre, and his criticism of more traditional approaches to literature still holds true:

"What tends to be taught is some critical orthodoxy, a set of ready-made judgements for rote learning rather than strategies of understanding which can be transferred... (Widdowson 1975:75).

Linguistic stylistics, by providing "strategies" for understanding how language works in all kinds of texts, opens the way to a better appreciation of the writer's craft and a more authentic response to literature. The picture is of course complicated by the many different linguistic models that can inform stylistics, and by the question of the extent to which linguistics should actually be taught at different levels. There can be little doubt, though, that teachers would be better equipped to foster the development of their students' understanding of literature if they themselves had some grounding in linguistics. What kind of linguistics? Preferably a model with 
a strong semantic orientation, and one in which, to quote Hasan (1985:105), one studies "not only language in society [...] but also society in language - how our structures of knowledge, our personalities, our social and political institutions are created and maintained by language". It is to be hoped that the analysis provided in this paper goes some way towards demonstrating the value and relevance of just such a model. 


\section{BIBLIOGRAPHY}

Austen, J. 1963 [1813] Pride and prejudice. London: Everyman.

Britt, K. 1976 The emerald garden. London: Mills and Boon.

Carter, R. 1988 "Some pawns for Kingman: language education and English teaching". Greenwell, $\mathrm{P}$ (ed) British studies in applied linguistics 3. London: CILT.

Carter, R. \& Nash, W. 1990 Seeing through language. Oxford: Blackwell.

Fillmore, C.J. 1977 "The case for case reopened." Cole, P. and Sadock, J.M. (eds) Syntax and semantics vol. 8. New York: Academic Press.

Halliday, M.A.K. 1971 "Linguistic function and literary style: an inquiry into William Golding's The Inheritors." Halliday, M.A.K. Explorations in the runctions of language. Oxford: Oxford University Press.

Halliday, M.A.K. 1985 An introduction to functional grammar. London: Edward Arnold.

Hasan, R. 1988 "The analysis of one poem: theoretical issues in practice" Birch, D. and O'Toole, M. (eds) Functions of style. London: Pinter: $45-73$.

Hasan, R. 1989 Linguistics, language and verbal art. Oxford: OUP.

Kennedy, C. 1982 "Systemic grammar and its use in literary analysis." Carter, R. (ed.) Language and litcrature. London: Allen and Unwin: 83-100.

Ker, M. 1985 Hostage. London: Mills and Boon.

Kies, D. 1992 "The uses of passivity: suppressing agency in Nineteen Eighty-Four". Davies, M and Ravelli, L (eds) Advances in systemic linguistics. London: Pinter: 229-250.

Widdowson, H.G. 1975 Stylistics and the teaching of literature. London: Longman. 